\title{
Technical note: Optimization of lactose quantification based on coupled enzymatic reactions
}

\author{
Luis Condezo-Hoyos, Indira P. Mohanty, and Giuliana D. Noratto ${ }^{1}$ \\ School of Food Science, Washington State University, Pullman 99164
}

\begin{abstract}
A colorimetric microplate-adapted lactose assay was developed to quantify lactose in dairy products. The assay was based on the coupled enzymatic reaction of $\beta$-galactosidase-glucose oxidase-horseradish peroxidase using Amplex red as detection probe. The assay showed good linearity in the range of 0.1 to $0.5 \mathrm{mmol}$ of lactose/L, with a limit of detection of $0.0433 \mathrm{mmol} / \mathrm{L}$ and a limit of quantification of $0.1313 \mathrm{mmol} / \mathrm{L}$. The lactose assay at optimized conditions (5 U of $\beta$-galactosidase/ $\mathrm{mL}, 5 \mathrm{U}$ of glucose oxidase $/ \mathrm{mL}, 1 \mathrm{U}$ of horseradish peroxidase/mL, and $100 \mu \mathrm{mol}$ of Amplex red/L for 1 $\mathrm{h}$ at $37^{\circ} \mathrm{C}$ in the dark) showed good correlation with a commercial lactose enzymatic kit with intraassay variation below $10 \%$ and interassay variations below $7.6 \%$. The developed lactose microplate assay can be adopted as routine analysis for lactose determination in dairy products due to its relatively low cost compared with a commercial kit, relatively short reaction time, and high sensitivity and reproducibility.
\end{abstract}

Key words: lactose, $\beta$-galactosidase, enzymatic reaction

\section{Technical Note}

Lactose is a disaccharide sugar derived from galactose and glucose, which form a $\beta-1 \rightarrow 4$ glycosidic linkage. Intestinal absorption assimilation of this disaccharide requires hydrolysis to free glucose and galactose, a reaction catalyzed by lactase. Lactose intolerance in consumers with low lactase activity has promoted the development of a market for low-lactose or lactose-free products. Therefore, a protocol that can be implemented for routine analysis will have extensive application for analysis of lactose in dairy products.

Several analytical methods to quantify lactose have been published, including spectrophotometric (Harris, 1986; Shapiro et al., 2002; Fornera et al., 2011), chromatographic (Xinmin et al., 2008; Erich et al.,

Received August 29, 2013.

Accepted January 1, 2014.

${ }^{1}$ Corresponding author: giuliana.noratto@wsu.edu
2012), electrochemical methods using 5-aminosalycilic acid (Eshkenazi et al., 2000) or tetrathiafulvalene as probes to detect amperometric signals (Conzuelo et al., 2010), and a method that quantifies lactose indirectly by measuring the glucose released after enzymatic hydrolysis using a blood glucose biosensor (Amamcharla and Metzger, 2011). However, the chromatographic and electrochemical methods require instruments that are not usually available in laboratories for routine analysis.

The enzymatic cascade spectrophotometric method quantifies the glucose released from lactose by $\beta$-galactosidase and oxidized by glucose oxidase, which produces hydrogen peroxide $\left(\mathrm{H}_{2} \mathrm{O}_{2}\right)$ that oxidizes the $o$-phenylenediamine detection probe (Fornera et al., 2011). However, the reaction requires $7 \mathrm{~h}$, which makes the procedure time consuming and not practical for routine analysis.

Amplex red $(\mathbf{A R})$ is a colorless and nonfluorescent compound that is commonly used as a probe for the measurement of extracellular $\mathrm{H}_{2} \mathrm{O}_{2}$ in biological systems. Amplex red reacts with $\mathrm{H}_{2} \mathrm{O}_{2}$ in 1:1 stoichiometry to form colored and fluorescent resorufin, catalyzed by horseradish peroxidase (Rhee et al., 2010). Amplex redbased commercial assay kits have been developed for multiple analysis including glucose, galactose (Invitrogen Corp., Carlsbad, CA), and lactose (BioVision Inc., Milpitas, CA), which quantifies lactose through the galactose released. Our aim was to optimize a lactose assay based on the coupled enzymatic reactions using $\beta$-galactosidase-glucose oxidase-horseradish peroxidase and $\mathrm{AR}$ as detection probe to be implemented as routine analysis.

$\beta$-Galactosidase ( $\boldsymbol{\beta}$-Gal) from Escherichia coli grade VIII (G5635-1KU), glucose oxidase (GOD) from Aspergillus niger type VII (G2133-10KU), AR (901015MG-F), dimethyl sulfoxide (D8418-100ML), D-lactose monohydrate (61339-25G), horseradish peroxidase (HRP) type XII (P8415-500UN), magnesium chloride anhydrous (M8266-100G), sodium chloride (S7653250G), and sodium phosphate monobasic dehydrate (71505-250G) and dibasic (S7907-100G) were purchased from Sigma-Aldrich Co. Ltd. (St. Louis, MO). The lactose enzymatic kit (K624-100) was purchased from BioVision Inc. 
Reduced-fat milk, lactose-free milk, powder nonfat milk, and plain Greek yogurt were purchased from a local supermarket in Pullman, Washington. Whey from the American Cheddar cheese (Cougar Gold) and the Monterey Jack-style non-Cheddar cheese (Viking) processing were provided by the creamery at Washington State University (Pullman). Whey was subjected to UF (Romicon model HF-LAB-5; Koch Membrane Systems Inc., Wilmington, MA) to obtain whey permeate containing lactose and other sugars with a polyethersulfone membrane (10,000-Da cutoff). Powder milk and Greek yogurt were homogenized with water $(1: 10)$; a $1-\mathrm{mL}$ aliquot of sample was then mixed with $100 \mu \mathrm{L}$ of $20 \%$ (wt/vol) cold TCA and centrifuged at 21,130 $\times g$ for $5 \mathrm{~min}$ at $4^{\circ} \mathrm{C}$ to eliminate proteins. Supernatants were stored at $-20^{\circ} \mathrm{C}$ until analysis.

Serial dilutions ( 0.1 to $0.5 \mathrm{mmol} / \mathrm{L})$ of D-lactose were prepared from stock solution $(10 \mathrm{mmol} / \mathrm{L})$. A stock solution of $\beta$-Gal $(1,000 \mathrm{U} / \mathrm{mL})$ was prepared in PBS (50 mmol/L, $\mathrm{pH} 7.2$ ) containing $\mathrm{MgCl}_{2}(2 \mathrm{mmol} / \mathrm{L})$, GOD $(1,000 \mathrm{U} / \mathrm{mL})$, and HRP $(500 \mathrm{U} / \mathrm{mL})$. Amplex red was prepared in dimethyl sulfoxide at $10 \mathrm{mmol} / \mathrm{L}$. All solutions were stored at $-20^{\circ} \mathrm{C}$.

The spectrum of absorption of resorufin produced by oxidation of $\mathrm{AR}$ at reaction conditions (20 U of $\beta$-Gal/ $\mathrm{mL}, 5 \mathrm{U}$ of $\mathrm{GOD} / \mathrm{mL}, 1 \mathrm{U}$ of $\mathrm{HRP} / \mathrm{mL}$, and $100 \mu \mathrm{mol}$ of $\mathrm{AR} / \mathrm{L}$ at $37^{\circ} \mathrm{C}$ for $30 \mathrm{~min}$ in the dark, with 0.1 to 0.5 mmol of lactose standard/L) was monitored between 400 and $700 \mathrm{~nm}$ every $5 \mathrm{~nm}$ using an $\mu$ Quant microplate reader (BioTek Instruments Inc., Rochester, VT) to determine the wavelength for maximum absorption.

The hydrolysis of lactose by $\beta$-Gal is the first enzymatic reaction and limiting step in the lactose assay. Lactose $(0.5 \mathrm{mmol} / \mathrm{L})$ was hydrolyzed by $\beta$-Gal at 5 , 10 , and $20 \mathrm{U} / \mathrm{mL}$ in the presence of GOD $(5 \mathrm{U} / \mathrm{mL})$, $\operatorname{HRP}(1 \mathrm{U} / \mathrm{mL})$, and $\mathrm{AR}(100 \mu \mathrm{mol} / \mathrm{L})$ at $37^{\circ} \mathrm{C}$ for 120 min. The absorbances were monitored at $570 \mathrm{~nm}$ from 30 to 120 min.

Ten microliters of lactose standard $(0.1$ to 0.5 $\mathrm{mmol} / \mathrm{L}$ ) was mixed with $100 \mu \mathrm{L}$ of $\mathrm{AR}$ reagent (ARR) containing $\beta$-Gal $(5 \mathrm{U} / \mathrm{mL})$, GOD $(5 \mathrm{U} / \mathrm{mL})$, HRP (1 $\mathrm{U} / \mathrm{mL})$, and AR $(100 \mu \mathrm{mol} / \mathrm{L})$ dissolved in PBS on a 96-well plate. Absorbances at $570 \mathrm{~nm}$ were monitored every $2 \mathrm{~min}$ in reactions incubated at 20 and $37^{\circ} \mathrm{C}$ for $30 \mathrm{~min}$. Linear regression analysis was used to calculate the slopes of each standard curve and slope values were used to compare effects of time and temperature on the reaction.

Dietary antioxidants at biological concentrations produce interferences in the AR/HRP catalyzed reaction (Serrano et al., 2009) that might result in overquantification of lactose. Dairy products were assessed for interferences due to the presence of $\mathrm{H}_{2} \mathrm{O}_{2}$ or antioxidant activity that can catalyze AR-HRP reactions.
Briefly, samples were diluted in PBS (1:600 for milk and lactose-free milk, 1:1,000 for powder milk, 1:100 for Greek yogurt, and 1:300 for whey cheese permeates); a $10-\mu \mathrm{L}$ sample or PBS (blank) was mixed with $100 \mu \mathrm{L}$ of AR $(100 \mu \mathrm{mol} / \mathrm{L})$ and $\operatorname{HRP}(1 \mathrm{U} / \mathrm{mL})$. Absorbances at $570 \mathrm{~nm}$ after incubation at $37^{\circ} \mathrm{C}$ for $1 \mathrm{~h}$ were compared with the blank.

In addition, antioxidant activities of samples were assessed by the $\mathrm{ABTS}^{\bullet+}$ assay as previously reported (Re et al., 1999). Briefly, 2,2'-azinobis-(3-ethylbenzothiazoline-6-sulfonic acid) $\left(\mathbf{A B T S}^{\boldsymbol{+}}\right)$ produced by reaction of $7 \mathrm{mmol}$ of ABTS/L with $2.45 \mathrm{mmol}$ of potassium persulfate/L for $16 \mathrm{~h}$ at room temperature in the dark was diluted with PBS to reach an absorbance of approximately 0.80 at $405 \mathrm{~nm}$. A $10-\mu \mathrm{L}$ aliquot of diluted sample or Trolox $(0-300 \mu \mathrm{mol} / \mathrm{L})$ and $200 \mu \mathrm{L}$ of $\mathrm{ABTS}^{\bullet+}$ working solution were added to a 96-well plate and incubated for $6 \mathrm{~min}$ at room temperature. Antioxidant activity was monitored at $405 \mathrm{~nm}$ against the standard curve of Trolox and expressed as $\mu \mathrm{mol}$ of Trolox equivalent/L.

To evaluate the effect of initial glucose concentration in diluted samples, a stock solution of ARR without $\beta$-Gal $\left(\mathbf{A R R}^{-\gamma-} \boldsymbol{\beta}-\mathbf{G a l}\right)$ was used. Lactose content in the samples was calculated by subtracting the absorbance obtained in the $\mathrm{ARR}^{-1-} \beta-\mathrm{Gal}$ reaction from the absorbance obtained with the ARR reaction.

Standard curves of lactose were constructed to evaluate the linearity of the enzymatic assay. Reactions were carried out with lactose standard $(0.1$ to $0.5 \mathrm{mmol} / \mathrm{L})$ and $100 \mu \mathrm{L}$ of ARR stock solution at $37^{\circ} \mathrm{C}$ for $1 \mathrm{~h}$. The linearity was evaluated by the coefficient of determination and residual plot obtained from regression analysis. The sensitivity of the assay was evaluated by the limit of detection (LOD) and limit of quantification (LOQ). The LOD and LOQ were calculated from standard curves (Shewiyo et al., 2012) as follows: LOD $=3.3 \sigma / \mathrm{S}$ and $\mathrm{LOQ}=10 \sigma / \mathrm{S}$ where $\sigma$ was the standard deviation for absorbance of the blank $(\mathrm{n}=3)$ and $\mathrm{S}$ was the slope of the standard curve.

The intraassay and interassay variations were evaluated through the relative standard deviation (RSD) percentage. For intraassay variations, 3 replicates of 5 different samples were run in $1 \mathrm{~d}$ and RSD percentage $=(\mathrm{SD} /$ mean of each sample $) \times 100$. For interassay variations, the same sample was analyzed on 3 different days and RSD percentage $=(\mathrm{SD} /$ mean value of $3 \mathrm{~d})$ $\times$ 100. A lactose enzymatic commercial assay kit (Lab Vision Corp., Fremont, CA) was used to validate our lactose assay.

Ten microliters of sample or lactose standard (0.1-0.5 $\mathrm{mmol} / \mathrm{L}$ ) and $100 \mu \mathrm{L}$ of $\mathrm{ARR}$ or $\mathrm{ARR}^{-/-} \beta-\mathrm{Gal}$ were mixed for $15 \mathrm{~s}$ on a 96-well plate using a titer plate shaker at speed $=6($ Thermo Scientific, Asheville, NC) 


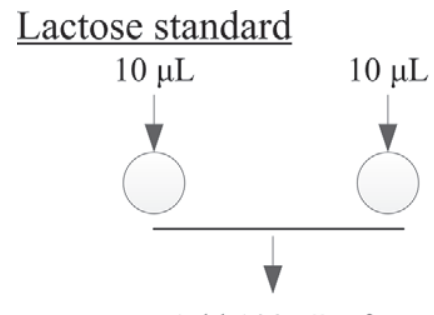

Add $100 \mu \mathrm{L}$ of

ARR-1
Sample

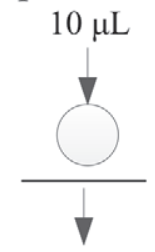

Add $100 \mu \mathrm{L}$ of

ARR-2

96-well plate

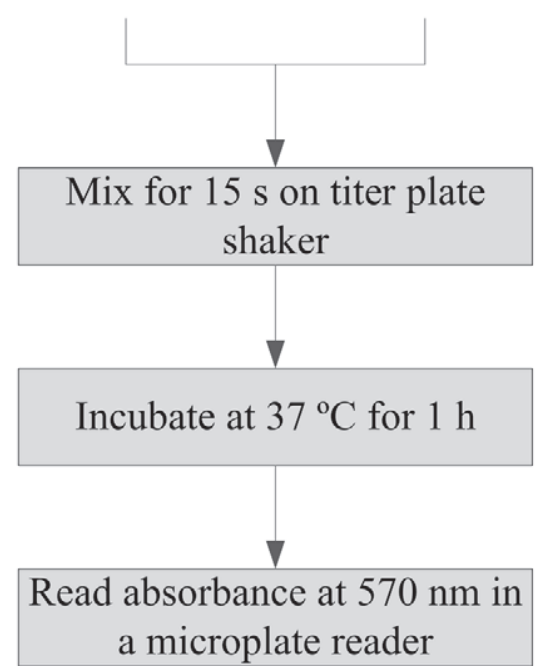

Figure 1. Procedure for the lactose assay. Amplex red (AR) reagent 1 (ARR-1) comprised $\beta$-Gal $(5 \mathrm{U} / \mathrm{mL})$, glucose oxidase (GOD; $5 \mathrm{U} / \mathrm{mL}$ ), horseradish peroxidase (HRP; $1 \mathrm{U} / \mathrm{mL}$ ), and AR (100 $\mu \mathrm{mol} / \mathrm{L})$ dissolved in PBS $(50 \mathrm{mmol} / \mathrm{L}, \mathrm{pH} 7.2)$; ARR-2 comprised GOD $(5 \mathrm{U} / \mathrm{mL})$, HRP $(1 \mathrm{U} / \mathrm{mL})$, and AR $(100 \mu \mathrm{mol} / \mathrm{L})$ dissolved in PBS (50 mmol/L, pH 7.2).

and then incubated at $37^{\circ} \mathrm{C}$ for $1 \mathrm{~h}$, as illustrated in Figure 1, and absorbance at $570 \mathrm{~nm}$ was recorded.

One-way ANOVA followed by a Bonferroni post-hoc test and linear regression analysis were performed using GraphPad Prism software (GraphPad Software Inc., San Diego, CA). A value of $P<0.05$ was considered statistically significant.

The spectrum of absorption in the presence of lactose (0.0 to $0.5 \mathrm{mmol} / \mathrm{L}), \beta-\mathrm{Gal}(20 \mathrm{U} / \mathrm{mL})$, GOD $(5 \mathrm{U} /$ $\mathrm{mL})$, and $\operatorname{HRP}(1 \mathrm{U} / \mathrm{mL})$ revealed a maximum absorbance at $570 \mathrm{~nm}$ for oxidation of AR (Figure 2), which was associated with resorufin formation by oxidation of AR (Rhee et al., 2010; Rodrigues and Gomes, 2010). A slight increase in absorbance at $570 \mathrm{~nm}$ was observed in the sample without lactose (Figure 2, red arrow), which indicates AR oxidation levels due to the presence of light and traces of resorufin (Zhao et al., 2012). Therefore, an important recommendation for lactose assay is to protect the working AR solution from light and to run the experiment in the dark.

Absorbance of reactions increased by increasing $\beta$-Gal concentration (from 5 to $20 \mathrm{U} / \mathrm{mL}$ ) and reaction

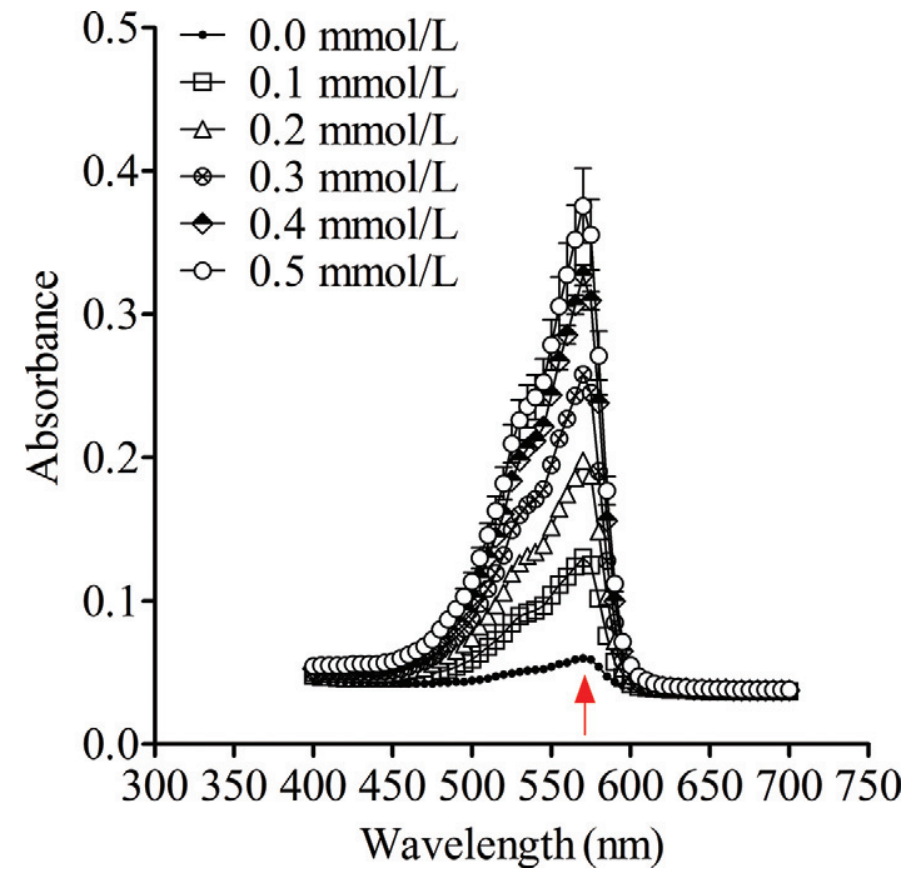

Figure 2. Spectrum of absorption in the presence of lactose $(0.0$ to $0.5 \mathrm{mmol} / \mathrm{L}), \beta$-Gal $(20 \mathrm{U} / \mathrm{mL})$, glucose oxidase (GOD; $5 \mathrm{U} / \mathrm{mL}$ ), and horseradish peroxidase (HRP; $1 \mathrm{U} / \mathrm{mL}$ ). A maximum absorbance at $570 \mathrm{~nm}$ was observed for oxidation of amplex red (AR), which was associated with resorufin formation by oxidation of AR (Rhee et al., 2010; Rodrigues and Gomes, 2010). A slight increase in absorbance at $570 \mathrm{~nm}$ was observed in the sample without lactose (red arrow), which indicates AR oxidation levels due to the presence of light and traces of resorufin (Zhao et al., 2012). Color version available in the online PDF.

time (from 30 to 120 min; Figure 3). Absorbance at 75 min of reaction with $5 \mathrm{U}$ of $\beta-\mathrm{Gal} / \mathrm{mL}$ was similar to the $30-\mathrm{min}$ reaction with $20 \mathrm{U}$ of $\beta-\mathrm{Gal} / \mathrm{mL}$. However, the 60 -min reaction with $5 \mathrm{U}$ of $\beta-\mathrm{Gal} / \mathrm{mL}$ had twice the absorbance obtained when using the o-phenylenediamine probe and 7-h reaction standard conditions $\left(25^{\circ} \mathrm{C}, 1.4 \mathrm{U}\right.$ of $\beta-\mathrm{Gal} / \mathrm{mL}, 0.002 \mathrm{U}$ of $\mathrm{GOD} / \mathrm{mL}$, and $0.03 \mathrm{U}$ of HRP $/ \mathrm{mL}$; Fornera et al., 2011). Therefore, we chose $5 \mathrm{U}$ of $\beta-\mathrm{Gal} / \mathrm{mL}$ for our ARR stock solution and a 60 -min reaction time.

Incubation at $37^{\circ} \mathrm{C}$ increased the average slope $(\mathrm{S})$ of the lactose standard curves by $2.5 \pm 0.2$-fold compared with incubation at $20^{\circ} \mathrm{C}$ (slopes were calculated between 12 and 30 min reaction; Figure 4 and Table 1). The coefficient of variation for each slope was below $10 \%$. The sensitivity of our assay is given by the LOD values $(3.3 \sigma / \mathrm{S})$, where $\sigma=0.047$ at both temperatures (20 and $37^{\circ} \mathrm{C}$ ); therefore, the LOD at $37^{\circ} \mathrm{C}$ was $40 \%$ of the LOD at $20^{\circ} \mathrm{C}$. Even more, the slope of the standard curve at $37^{\circ} \mathrm{C}$ after 30 min of reaction $(0.261$; Table 1$)$ was comparable with the slope obtained by Fornera et al. (2011) after $7 \mathrm{~h}$ of reaction $(\sim 0.27)$. Therefore, $37^{\circ} \mathrm{C}$ was selected as the optimal assay temperature. 


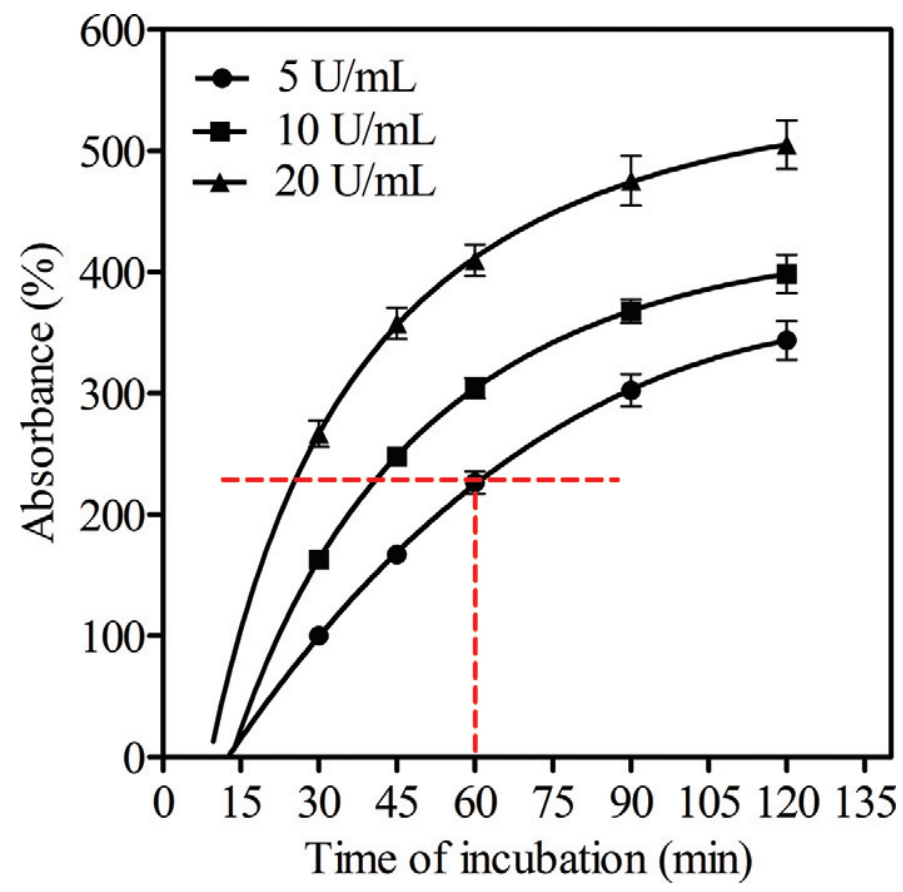

Figure 3. Absorbance of reactions with increasing $\beta$-Gal concentration (from 5 to $20 \mathrm{U} / \mathrm{mL}$ ) and reaction time (from 30 to $120 \mathrm{~min}$ ). Absorbance at $75 \mathrm{~min}$ of reaction with $5 \mathrm{U}$ of $\beta-\mathrm{Gal} / \mathrm{mL}$ was similar to the 30-min reaction with $20 \mathrm{U}$ of $\beta-\mathrm{Gal} / \mathrm{mL}$. However, the $60-\mathrm{min}$ reaction with $5 \mathrm{U}$ of $\beta-\mathrm{Gal} / \mathrm{mL}$ had twice the absorbance (indicated by the cross section of the red dashed lines) obtained when using the $o$-phenylenediamine probe and 7-h reaction standard conditions $\left(25^{\circ} \mathrm{C}\right.$, $1.4 \mathrm{U}$ of $\beta-\mathrm{Gal} / \mathrm{mL}, 0.002 \mathrm{U}$ of $\mathrm{GOD} / \mathrm{mL}$, and $0.03 \mathrm{U}$ of $\mathrm{HRP} / \mathrm{mL}$; Fornera et al., 2011). Color version available in the online PDF.

Diluted samples were assayed. Results showed that absorbance at $570 \mathrm{~nm}$ in sample reactions with ARHRP were not different from the blank (data not shown). Similar results were obtained from the $\mathrm{ABTS}^{\bullet+}$ assay, with antioxidant activities of diluted samples comparable with blanks. In addition, the interference produced by initial glucose in diluted samples used for

Table 1. Changes in absorbance with respect to the blank were observed after 12 min of incubation

\begin{tabular}{llcc}
\hline & \multicolumn{3}{c}{ Slope of the lactose standard curve } \\
\cline { 2 - 4 } $\begin{array}{l}\text { Incubation time } \\
\text { (min) }\end{array}$ & $20^{\circ} \mathrm{C}$ & $37^{\circ} \mathrm{C}$ & $\begin{array}{c}\text { Ratio } \\
37^{\circ} \mathrm{C} / 20^{\circ} \mathrm{C}\end{array}$ \\
\hline 12 & 0.016 & 0.047 & 2.938 \\
14 & 0.022 & 0.059 & 2.682 \\
16 & 0.030 & 0.076 & 2.533 \\
18 & 0.038 & 0.095 & 2.500 \\
20 & 0.049 & 0.119 & 2.429 \\
22 & 0.060 & 0.144 & 2.400 \\
24 & 0.069 & 0.170 & 2.464 \\
26 & 0.082 & 0.200 & 2.439 \\
28 & 0.096 & 0.231 & 2.406 \\
30 & 0.111 & 0.261 & 2.351 \\
\hline
\end{tabular}
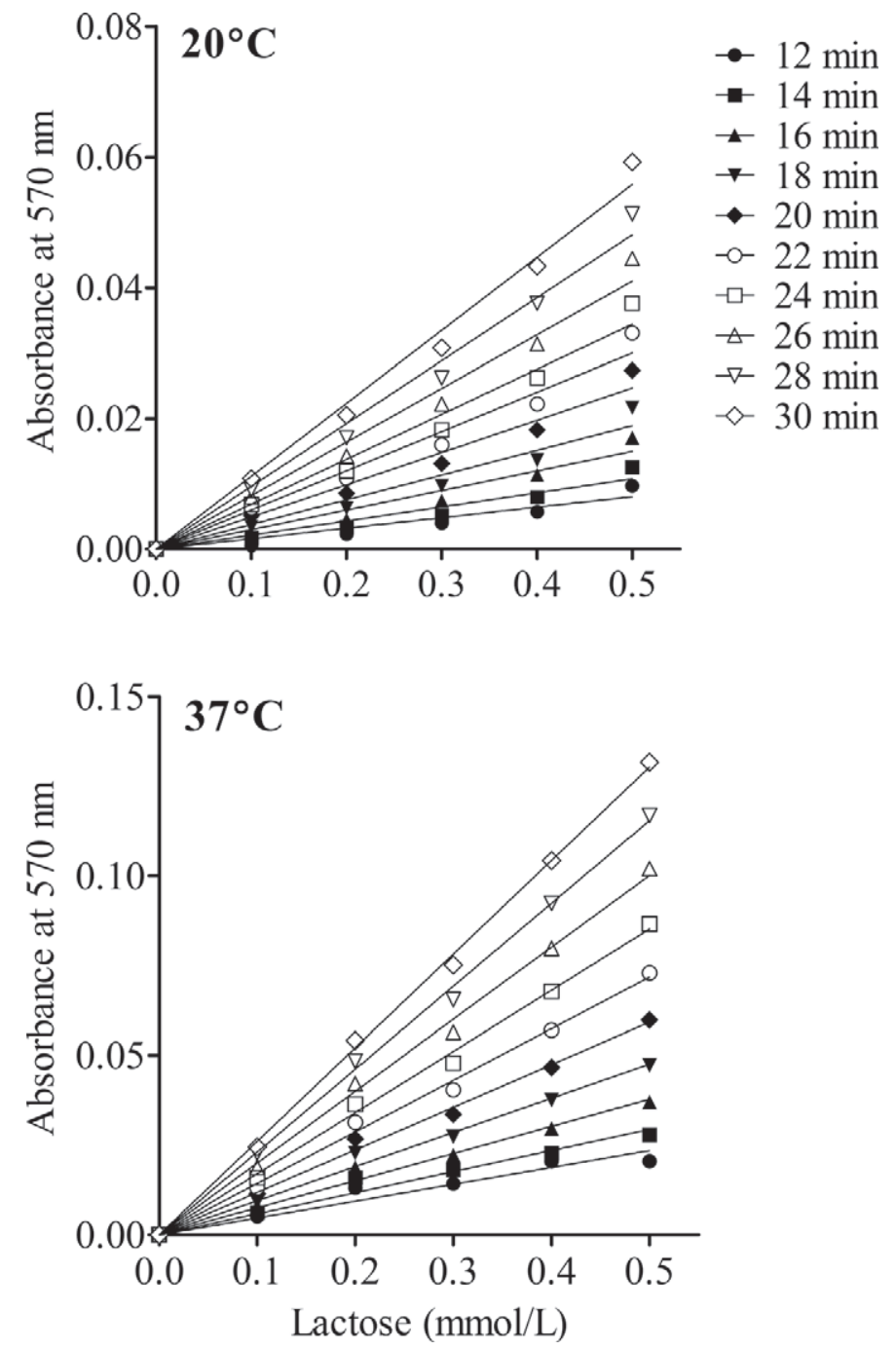

Figure 4. Effects of temperature on the lactose standard curves for different durations of incubation.

the ARR reaction was very low and comparable with blanks.

The linearity of our lactose assay was assessed in the range 0.1 to $0.5 \mathrm{mmol} / \mathrm{L}$ at $37^{\circ} \mathrm{C}$ and 1 -h reaction with ARR. Results showed a coefficient of determination of 0.999 and the residual plot graph with expected random distribution (data not shown), which confirm the linearity of our assay. The LOD was $0.0433 \mathrm{mmol} / \mathrm{L}$ and the LOQ was $0.131 \mathrm{mmol} / \mathrm{L}$. As previously discussed and based on slope values, which are inversely related to LOD and LOQ values, our assay is comparable with the assay developed by Fornera et al. (2011), with the advantage of a significantly lower reaction time $(1$ vs. $7 \mathrm{~h}$ ). Lower LOD have been reported only in methods using more sophisticated instruments, such as the amperometric biosensor $(\mathrm{LOD}=0.46 \mu \mathrm{mol} / \mathrm{L}$; Conzuelo et al., 2010) and the ion-pair reversed-phase 
Table 2. Lactose content, including intra- and interassay variations [relative SD (RSD) percentage $]^{1}$

\begin{tabular}{|c|c|c|c|c|c|}
\hline Item & \multicolumn{4}{|c|}{ Lactose content ${ }^{2}$} & $\begin{array}{l}\text { Lactose content } \\
\text { enzymatic kit }\end{array}$ \\
\hline Fluid milk reduced fat & $105.3 \pm 4.7$ & $106 \pm 4.6$ & $109 \pm 4.9$ & 1.8 & $92.9 \pm 2.3$ \\
\hline Powder fat-free milk & $52.8 \pm 2.3$ & $53.8 \pm 1.5$ & $51.5 \pm 2.1$ & 2.2 & $44.8 \pm 0.9$ \\
\hline Plain Greek yogurt & $5.1 \pm 0.4$ & $5.8 \pm 0.4$ & $5.0 \pm 0.3$ & 8.2 & $8.6 \pm 0.2$ \\
\hline \multicolumn{6}{|l|}{ Intraday RSD percentage } \\
\hline Lowest & 4.4 & 2.8 & 4.1 & & \\
\hline Highest & 9.2 & 10.3 & 9.8 & & \\
\hline
\end{tabular}

${ }^{1}$ Values represent mean $\pm \mathrm{SD}(\mathrm{n}=3)$.

${ }^{2}$ Lactose was quantified as grams per liter for liquid samples and as grams per $100 \mathrm{~g}$ for solid samples. Intraday variation (lowest and highest RSD were calculated among all samples analyzed on each day) and interassay variation was calculated for each sample analyzed on different days (as detailed in the Materials and Methods section).

${ }^{3}$ Lab Vision Corp. (Fremont, CA).

${ }^{4} \mathrm{ND}=$ not detectable.

HPLC (LOD $=5.8 \mu \mathrm{mol} / \mathrm{L}$; Erich et al., 2012) and are difficult to be implemented as routine analysis for lactose determination.

Data from lactose quantification in dairy products under optimized conditions $\left(\mathrm{ARR}, 37^{\circ} \mathrm{C}\right.$, and 1 -h reaction time) following the protocol illustrated in Figure 1 were used to calculate the intra- and interassay variations (Table 2). The intraassay variations (RSD percentage) of different samples analyzed on each day were within 4.4 to $9.2 \%$ for d $1,2.8$ to $10.3 \%$ for d 2 , and 4.1 to $9.8 \%$ for $\mathrm{d} 3$. The lowest RSD percentage values were found in powder fat-free milk and the highest RSD percentage values were in whey permeates. The interassay variations (RSD percentage) of each sample analyzed on 3 different days were in the range 0.9 to $8.2 \%$ for whey permeates and yogurt. We validated our lactose assay using the commercial kit (Lab Vision Corp.; $\mathrm{r}=$ 0.97; $P<0.05)$.

We optimized a sensitive and specific colorimetric method to quantify lactose in dairy products at a reduced reaction time of $1 \mathrm{~h}$. Our lactose assay using the AR probe did not exhibit interference under the optimized conditions, having low intraassay and interassay variations and a good correlation with a commercial lactose enzymatic kit. In addition, this assay can be adopted as a routine method to quantify lactose in a time-efficient manner without sacrificing sensitivity.

\section{REFERENCES}

Amamcharla, J. K., and L. E. Metzger. 2011. Development of a rapid method for the measurement of lactose in milk using a blood glucose biosensor. J. Dairy Sci. 94:4800-4809.

Conzuelo, F., M. Gamella, S. Campuzano, M. A. Ruiz, A. J. Reviejo, and J. M. Pingarrón. 2010. An integrated amperometric biosensor for the determination of lactose in milk and dairy products. J Agric. Food Chem. 58:7141-7148.

Erich, S., T. Anzmann, and L. Fischer. 2012. Quantification of lactose using ion-pair RP-HPLC during enzymatic lactose hydrolysis of skim milk. Food Chem. 135:2393-2396.

Eshkenazi, I., E. Maltz, B. Zion, and J. Rishpon. 2000. A three-cascaded-enzymes biosensor to determine lactose concentration in raw milk. J. Dairy Sci. 83:1939-1945.

Fornera, S., K. Yazawa, and P. Walde. 2011. Spectrophotometric quantification of lactose in solution with a peroxidase-based enzymatic cascade reaction system. Anal. Bioanal. Chem. 401:2307-2310.

Harris, W. M. 1986. Automated determination of fat, crude protein and lactose in ewe milk by infrared spectrometry. Analyst 111:37-39

Re, R., N. Pellegrini, A. Proteggente, A. Pannala, M. Yang, and C. Rice-Evans. 1999. Antioxidant activity applying an improved ABTS radical cation decolorization assay. Free Radic. Biol. Med. 26:1231-1237.

Rhee, S. G., T. S. Chang, W. Jeong, and D. Kang. 2010. Methods for detection and measurement of hydrogen peroxide inside and outside of cells. Mol. Cells 29:539-549.

Rodrigues, J. V., and C. M. Gomes. 2010. Enhanced superoxide and hydrogen peroxide detection in biological assays. Free Radic. Biol. Med. 49:61-66.

Serrano, J., M. Jové, J. Boada, M. J. Bellmunt, R. Pamplona, and M. Portero-Otín. 2009. Dietary antioxidants interfere with Amplex red-coupled-fluorescence assays. Biochem. Biophys. Res. Commun. 388:443-449.

Shapiro, F., A. Shamay, and N. Silanikove. 2002. Determination of lactose and D-galactose using thio- $\mathrm{NAD}^{+}$instead of $\mathrm{NAD}^{+}$. Int. Dairy J. 12:667-669.

Shewiyo, D. H., E. Kaale, P. G. Risha, B. Dejaegher, J. SmeyersVerbeke, and Y. Vander Heyden. 2012. HPTLC methods to assay active ingredients in pharmaceutical formulations: A review of the method development and validation steps. J. Pharm. Biomed. Anal. 66:11-23.

Xinmin, W., Z. Ruili, L. Zhihua, W. Yuanhong, and J. Tingfu. 2008. Determination of glucosamine and lactose in milk-based formulae by high-performance liquid chromatography. J. Food Compost. Anal. 21:255-258.

Zhao, B., F. A. Summers, and R. P. Mason. 2012. Photooxidation of Amplex red to resorufin: Implications of exposing the Amplex red assay to light. Free Radic. Biol. Med. 53:1080-1087. 